\title{
Realising the ecosystem-service value of native woodland in Ireland
}

\author{
Craig Bullock ${ }^{1 *}$, Jerry Hawe ${ }^{2}$, Declan Little ${ }^{3}$ \\ From Third International Congress on Planted Forests \\ Bordeaux, France; Dublin, Ireland; and Porto and Estoril, Portugal. 16-21 May 2013
}

\begin{abstract}
Background: In common with many other countries, native forest in the Ireland is under pressure from a variety of sources. Although the area of forest has increased to $10.5 \%$ of the land area of Ireland, this is comprised mainly of exotic conifer species (6.8\%). Native species woodland represents only 100,000 hectares (1.4\%) of the land area. In addition, much of this area is fragmented and comprised of a narrow range of species. Just 20,000 hectares is represented by woodland resembling the ancient woodland that once covered much of Ireland.
\end{abstract}

Methods: This paper examines the natural capital value of the existing area of woodland as represented by the value of the ecosystem services it provides.

Results: The results demonstrate a significant economic value in excess of $€ 67$ million per year. We discuss the consequences of the erosion of this value that could result from continued mismanagement of native woodland. The results show that current government policy is failing to realise the economic value of native woodland and is deficient in terms of the continuity of support.

Conclusions: The paper demonstrates the very significant values that could be supplied by a gradual expansion of woodland area up to $100 \%$ of the current forested area, especially if this expansion is targeted at areas with the highest potential for amenity and water resource protection.

\section{Introduction}

Extensive forest once covered most of Ireland but, today, the Republic of Ireland is one of the least forested countries in Europe. Less than $10.5 \%$ of the land area (approx. 697,600 hectares) is forest and 68\% of this is occupied by commercial softwood species (Forest Service 2012). Excluding mixed and non-native broadleaf forest, only about 100,000 hectares of native woodland remain ${ }^{\mathrm{i}}$. Of this, approximately 20,000 hectares is defined as ancient woodland, i.e. woodland dating from the period (prior to the 1600s) before commercial planting began (Perrin and Daly, 2010). These remnants are not only a natural asset, but a natural capital asset that provides significant cultural, regulating and provisioning ecosystem services (Quine et al. 2011). Supporting ecosystem services (such as a habitat for specialist and non-

\footnotetext{
* Correspondence: craig.bullock@ucd.ie

${ }^{1}$ University College Dublin, Dublin 4, Ireland

Full list of author information is available at the end of the article
}

specialist species) also exist for each of these ecosystem services in one manner or another.(Quine et al. 2011)

This paper describes the particular ecosystem services provided by Ireland's native woodland. The objective is to demonstrate that cultural and regulating services, in addition to provisioning services, have an economic value, and that native woodlands are not just of esoteric or conservation interest. These values are at risk from a variety of threats such as spatial fragmentation, invasive species, deer browsing, poor management and inconsistent state support (Perrin et al. 2008; NPWS 2008; Purser et al. 2009). The intention is to demonstrate both the value of the existing area of woodland and to assess the potential benefits of an expansion of native woodland up to an area equal to that of the total current forested area. Although the focus of the study has clearly been on Ireland, an examination of these ecosystem service values has relevance to many other countries whose native woodland resource is small and dominated by a relatively

\section{SpringerOpen $^{\odot}$}


large commercial forest resource, or where native forest is vulnerable to neglect, loss and damage.

An assessment of the value of ecosystem services values and, by extension, the value of the natural capital stock, has relevance to land-use policy and the efficient allocation of resources. In Europe, the EU Biodiversity Strategy requires Member States to integrate ecosystem service values into national accounting and reporting systems by $2020^{\mathrm{ii}}$. This process will inform and coordinate decision-making and provide the foundation for a possible range of incentives to unlock natural capital values for the purpose of sustainable economic growth.

\section{Methods}

The natural capital value of existing native woodland was estimated using the following series of steps:

1) locating specific values that have been identified by previous studies;

2) drawing on values that have been calculated for the total forest area (coniferous and broadleaf) in instances where there are no previous studies of native woodland;

3) taking as a proportion the area that is represented by native woodland;

4) factoring up the value of this proportion by available evidence of the relative value of native woodland.

The economic value of cultural, regulating and provisioning ecosystem services, and of the biodiversity of forested land, is notoriously difficult to quantify. Qualitative information about the relationships between natural woodland and biodiversity, water quality, fish populations and flooding is available from scientific references but few of these provide quantitative data or estimates, especially the marginal quantitative estimates ideally needed for economic analyses. Indeed, the lack of primary data on many ecological functions is a problem for all studies that attempt to transform discussion of ecosystem services from the burgeoning theoretical literature into tangible indicators of economic value. Rather, the objective in the first instance is to demonstrate the importance of protecting native woodland for future ecosystem service provision.

\section{Results}

At present, the absolute value of ecosystem services from Ireland's native woodland is small simply because the remnant area of native woodland is small. However, because there is so little woodland, what remains has a premium value compared with non-native coniferous plantation, particularly for biodiversity and amenity. Furthermore, precisely because the stock of native woodland is small, any increase in the area of woodland can be expected to retain high levels of value without an imminent prospect of diminishing returns.

\section{Cultural services}

Various studies over the years have examined the public benefits of Irish forests, especially for amenity and landscape (Howley et al. 2011; Scarpa et al. 2000; Ni Dhubhain et al. 1994; Clinch 2006; Fitzpatrick Associates 2005; Upton et al. 2012b). However, no study appears to have been conducted in Ireland or the UK that is specific to native woodlands, although Upton et al. (2012a) examined the relative value of native species as an attribute within a choice experiment. Native woodland makes an important contribution to the Irish landscape. It is valued for amenity, including for the appreciation of birds and other wildlife, and is a setting for various passive and active recreation pursuits. Ancient woodlands also often contain archaeological features and evidence of old field patterns, coppicing and settlement (Perrin and Daly 2010; Byrnes 2007).

\section{Amenity}

At least 18 million visits are made each year to stateowned forests according to the Coillte, Ireland's semistate-sponsored forestry company, although the total number of visits to woodlands of all types has been reported as being up to 38 million $^{\text {iii }}$. Based on a number of previous surveys in Ireland and the UK (Gelan et al. 2007; Ni Dhubhain et al. 1994; Fitzpatrick Associates 2005), people's willingness-to-pay for a forest visit ranges from $€ 4$ to $€ 10$. Specialist users, such as mountain bikers, are estimated to value each such visit more highly, at $€ 18$ (Christie et al. 2006). The utility value of these trips could amount to $€ 168$ million per year. This estimate is based on the breakdown of types and frequency of use provided by Fitzpatrick Associates (2005) after allocating an average of $€ 7$ to irregular visits by Irish adults but half this figure to frequent visits ${ }^{\text {iv }}$. Most of this activity would, of course, occur in non-native coniferous forest as this type of forest predominates. Upton et al (2012a) estimated the relative marginal value of an increase in broadleaf area as being $30 \%$ more than that for an equivalent increase in non-native coniferous forest. If this relative marginal value is allocated to forest visits, the amenity value of the native component could be at least $€ 35$ million per year despite its relatively small area.

In principle, if the relative value of a visit to native woodland is higher than that to non-native forest, it should follow that the number of trips to native woodland will also be greater if all other factors, such as convenience, are equal. In this study, the same frequency of visits to both forest types has been assumed. This is because many native woodlands are small or located on private land, whereas many non-native forests are on public land 
and also have visitor facilities. Visits to forests tend to stimulate expenditure on accommodation, food and walking equipment. One third of forest and trail users were found to spend an average of just under $€ 15$ per trip, and approximately $5 \%$ of these spent $€ 64$ when staying overnight (Fitzpatrick Associates 2005). Proportionate domestic expenditure associated with native woodlands could, therefore, amount to $€ 14$ million. Some prime destinations, such as Glendalough and the Killarney National Park, are forested largely with native species and attract over one million visitors each year while some of Ireland's most wooded counties also attract large numbers of overseas tourists ${ }^{\mathrm{v}}$. Tourists are attracted by the scenic and recreational values but, in the absence of quantitative evidence of this contribution, only $5 \%$ of these visits have been attributed to the native woodland component. On this basis, foreign visitor expenditure could amount to $€ 10$ million per year, contributing to a total of estimate of expenditure of $€ 24$ million.

\section{Health benefits}

Forest amenity also contributes to health, both through psychological health and wellbeing and the role of physical exercise in combating obesity, cardio-vascular disease, stroke and cancer (CJC Consulting 2005). This provides two utility values, one which users attach to their own good health, and the other for public good benefits such as reduced sick days and savings on healthcare expenditure. Some studies have suggested a positive relation between nature and reduced stress levels (e.g. (Ulrich 1983; Kaplan and Talbot 1983; Laumann et al. 2003). However, it is notoriously difficult to attribute health benefits to any one environment (Sunderland 2012). A proportion of the perceived personal health benefits would be captured within the per-visit willingness-to-pay estimates above, but public benefits such as reduced health-care costs and absenteeism from work must also be acknowledged. No quantitative, applied surveys exist on the exercise habits of forest users. However, it is possible to estimate the benefits of such exercise using figures provided by CJC Consulting (2005). For example, if $1 \%$ of the $34 \%$ of Irish people regularly visiting forests (Fitzpatrick Associates 2005) were previously inactive (i.e. 3,800 people) in any one year, then the benefits of this exercise would amount to $€ 15$ million in reduced healthcare expenditure and increased productivity. Previous studies have applied an arbitrary reduction of $75 \%$ to these benefit estimates because other exercise opportunities are available (Regeneris 2009). This modification reduces the value associated with the existing area of native woodland to less than $€ 1$ million per year. However, as it fails to account for other benefits such as the contribution to mental health and children's spatial and social development (O'Brien and Murray 2005), we estimate actual benefits of $€ 2-3$ million per year.

\section{Regulating services Flood reduction}

Although forest cover can reduce water supply to the ground and aquifers (Soulsby and Reynolds 1995), water availability is only occasionally an issue in Ireland. Excess flow is a more familiar problem. The insurance costs of recent flooding in Ireland have been estimated at $€ 46$ million $^{\mathrm{vi}}$. In the UK, a property with an annual $1 \%$ risk of flooding has an estimated annual equivalent damage of nearly $€ 100$ (Penning-Rowsell et al. 2005). Native woodland does not remove the risk of flooding, but does have a moderating effect on run-off. Base flows have been reported to represent a higher proportion of total flows of around $60 \%$ compared with $20 \%$ in nonforested catchments (Neary et al. 2008; Kilfeather 2000). Peak flows in forests are extended by 20-140 minutes (Thomas and Nisbet 2007) reducing the risk of flash flooding. Differences in tree density, ground flora, topography, soil and geological conditions make it very difficult to extend these estimates to general predictions.

\section{Water quality}

The EU Water Framework Directive (2000/60/EC) requires that water authorities achieve a target of achieving "good water status" by 2015 . Only $52 \%$ of Irish rivers are currently of "good" quality status, largely due to eutrophication (EPA 2010). Woodland has the capacity to absorb nutrients that would otherwise enter watercourses, particularly if planted in buffer strips (Machava et al. 2007). The one study of public preference for water quality improvements conducted to date in Ireland (Stithou 2011) indicates a willingness-to-pay (in terms of additions to water charges) of $€ 32$ and $€ 66$ per year for small and large improvements respectively. The survey was undertaken three years prior to the controversial introduction of water charges, but the amounts are broadly consistent with those from other European studies.

Game angling for salmon is of economic value but numbers have declined in recent decades for various reasons. Terrestrial factors include declining water quality, land drainage and obstructions such as poorly designed weirs (IFI 2011). An Indecon report in (2003) showed that each rod-caught salmon was worth $€ 420$ 440 in terms of direct tourism expenditure. The capital value of fishing rights also relates to catch expectations with each salmon caught estimated to contribute $€ 2,000-€ 8,000$ to the economy ${ }^{\text {vii }}$. Here again, there is uncertainty as to the exact relationship between forestry and fish populations. Broadleaf species or alluvial woodland appear to enhance the habitat of salmonid species and to provide protection from bank erosion and polluted run-off, whereas large-scale conifer planting may reduce trout numbers (Allott et al. 1997). Shade, temperature moderation and associated food availability 
(e.g. falling debris and invertebrates) contribute to salmonid numbers and to the survival of fry (Broadmeadow and Nisbet 2004; Malcolm et al. 2008). Lehane et al. $(2001 ; 2002$; 2004) found that overhanging vegetation and pooling (including where created by woody debris) contributed most to trout numbers on rivers surveyed in Ireland.

\section{Carbon sequestration}

Broadleaved trees grow more slowly than conifers in Ireland's temperate climate and their rates of carbon sequestration are, therefore, lower. Sequestration by oak in the UK has been estimated at $1.8 \mathrm{t} \mathrm{C} \mathrm{ha}^{-1} \mathrm{yr}^{-1}$ on Yield-Class-4 sites (Dewar and Cannell 1992; Cannell and Milne 1995), although higher figures have been estimated for Irish trees (Black et al. 2006). Ireland's stock of native woodland is comprised largely of mature trees. The biomass of large trees contains a great deal of carbon but their growth rates will be low and so sequestration of further carbon will be small. In contrast, young trees will grow much faster. Assuming that only one fifth of the area is comprised of young trees (based on Forest Service planting figures ${ }^{\text {viii }}$ ), annual sequestration is estimated as being 30,000 t C $\mathrm{yr}^{-1}$. Carbon storage by trees on higher yield-class sites has been estimated at up to $115 \mathrm{t} \mathrm{C} \mathrm{ha}^{-1}$ and as much as $298 \mathrm{t} \mathrm{C} \mathrm{ha}^{-1}$ once the carbon content of the soil is included (Bailey et al. 2006). ${ }^{\text {ix }}$ Products made of hardwood do not necessarily have a longer life cycle than those from softwood (aside from the use of softwoods for pallets or pulp). However, a large proportion of broadleaf trees have been planted for non-timber purposes (Perrin et al, 2008), so much of this carbon will remain in long-term store. An expansion of the area of planted native woodland, plus the relatively long lifetime of broadleaved forest, are both positive factors in buying society time to deal with the likely effects of climate change. Estimates of the economic value of carbon sequestration by native woodland in Ireland range from $€ 2-8$ million per year.

\section{Provisioning services}

\section{Timber production}

Hardwood prices in Ireland and globally were depressed by international over-capacity between 1989 and 2008, and fell by as much as $75 \%$ in real terms during that period (Valatin and Starling 2010). They have rebounded in recent years to around $€ 60 \mathrm{~m}^{-3}$, with high quality grades selling at $€ 100-€ 300 \mathrm{~m}^{-3}$. ${ }^{\mathrm{x}}$ However, the quality of the available standing stock of native trees is poor and limited as these trees have not been managed for timber (Perrin et al, 2008). The National Forest Inventory (Forest Service 2007) estimated the total timber volume of broadleaf forest at 11 million $\mathrm{m}^{3}$ but, based on current production levels, the current standing value of sawlog output from native woodland is estimated to be only $€ 1.4$ million per year.

\section{Fuelwood}

Recently, demand for fuelwood has increased as more households install wood-burning stoves. ${ }^{x i}$ Also, national policy on renewable energy has set a target of $30 \%$ for woody biomass fuel in peat-fired power stations by 2015 . This demand has bolstered hardwood prices and has led to an expansion in the fuelwood market from around 60,000 $\mathrm{m}^{3}$ (Blackstock and Binggeli 2000) to 200,000 $\mathrm{m}^{3}$ with an estimated value of $€ 29$ million per year (Coford 2011). Although supplied partly from short-rotation forest, this increase is providing an incentive for improved silvicultural practices, including more regular thinning. Using the following assumptions (that one fifth of the existing area of native woodland is thinned or is subject to wood collection annually, fuelwood price is $€ 50 \mathrm{~m}^{-3}$ and potential volumes are $10-20 \mathrm{~m}^{3} \mathrm{ha}^{-1}$ ), the current area of native woodland could provide a gross income of $€ 2-4$ million per year.

\section{Supporting services \\ Biodiversity and habitat value}

Supporting ecosystem services underpin all the cultural, regulating and provisioning services in one manner or another. Native woodland tends to contain a greater number of species than planted forest (Sweeney et al. 2010), but a limited knowledge of ecosystem processes makes it extremely difficult to attribute a value to biodiversity. Some information can be obtained indirectly through the valuation of the benefits associated with the ecosystem services outlined above. For instance, the potential for wildlife sighting contributes to the amenity value of native woodland and should be captured within cultural ecosystem service values. Of non-use values measured in UK surveys, Garrod and Willis (1997) reported that biodiversity increases willingness-to-pay by $70 \%$ compared with basic forestry scenarios.

\section{Threats to Ireland's native woodlands}

A recent report on the status of EU Protected Habitats and Species (NPWS 2008) describes the condition of the four main types of Irish native woodlands designated under the Habitats Directive. Bog woodland is classified as "poor", while old oak (mainly Quercus petraea) woodland, alluvial woodland and yew (Taxus baccata) woodland are each considered to be "bad". These ratings result from a combination of factors: spatial fragmentation; invasion of unwanted plant species; browsing by deer, grazing by livestock and grey squirrel (Sciurus carolinienis) damage; and a prolonged absence of management. Each of these factors is discussed below.

Ireland's native woodlands are highly fragmented with most being less than five hectares in size (Perrin et al, 
2008). Twenty-five percent contains only three or four species (Gallagher et al. 2001; Perrin and Daly 2010). Fragmentation reduces the potential for colonisation by other fauna and flora. Climate change is likely to exacerbate this problem as specific habitats may decline and thus become even more isolated. Some spatial connectivity is provided by overlapping species or coniferous plantations and by Ireland's extensive network of hedgerows (Pithon et al., 2005; Foulkes et al., 2013).

Invasive plant species are a serious problem. Rhododendron (R. ponticum) was identified at $25 \%$ of the sites listed in the National Survey of Native Woodlands (Perrin et al, 2008). Other invasive species include cherry laurel (Prunus iaurocerus), Himalayan balsam (Impatiens glandulifera) and giant hogweed (Heracleum mantegazzianum) as well as naturalised beech and sycamore. Rhododendron is a particular problem due to its spreading habit which shades out ground flora and tree seedlings (Barron 2007). While its flowers attract insects, the toxicity of its foliage reduces its attraction to native insect species (Cross 1975; Judd and Rotherham 1992).

Populations of introduced grey squirrel and deer have increased dramatically in size due to the extensive planting of coniferous forest. Numbers of semi-native red deer (Cervis elaphus) and introduced sika (Cervus nippon) and fallow deer (Dama dama) increased by $565 \%$, $353 \%$ and $174 \%$ respectively between 1978 and 2008 (Carden et al. 2011). According to Purser et al. (2009), deer browsing is now having a serious impact on forest productivity, and planting of broadleaf forest in areas with large deer populations has become almost untenable. ${ }^{\text {ii }}$ In addition, regeneration in many woodlands is prevented by livestock grazing.

Many of these problems are themselves symptoms of a pervasive problem of under-management of woodlands (Perrin et al, 2008). Many of Ireland's woodlands are now over-mature and vulnerable to storm damage, pests or disease including the recent arrival of ash dieback (Chalara fraxinea $\mathrm{T}$. Kowalski). Many have passed through ownership changes, periods of political instability and economic recessions, and have not received any silvicultural management for generations (Cross 2012; Perrin et al. 2008). Timber output is not an objective of the majority of native woodland owners, although the current value of fuelwood is an incentive for improved management including the control of invasive species. The National Forest Inventory (Forest Service 2007) reported that trees in almost all oak woodlands had not been pruned or shaped. Results from the National Survey of Native Woodlands (Perrin et al, 2008) confirmed that only $3.8 \%$ of timber was of marketable quality. The small stock of native woodland and lack of management means that the supply chain and market are undeveloped with much sold timber derived from storm-damaged trees.

\section{Forestry assistance schemes and their effectiveness}

The Native Woodland Scheme (NWS) was launched in 2001 and provides support to landowners through grants, annual premium payments, and partial subsidies for deer fencing. The NWS consists of two elements; 'NWS1 Conservation' providing an incentive for the restoration of degraded woodlands and 'NWS2 Establishment' supporting new plantings. This scheme has been complemented by other schemes, such as the Woodland Improvement Scheme, which aims to improve the condition of existing woodland for timber output, and the Neighbourwood Scheme, which encourages applications from communities for amenity plantings. In addition, the standard Afforestation Scheme, which is focused on commercial plantings, contains a $10 \%$ requirement for broadleaf forest. Between 2002 and 2011, 2,542 hectares of existing native woodland were restored and 1,053 hectares of new native woodlands planted. However, state financial support has been inconsistent and this has discouraged foresters and landowners. Element 1 of the NWS has been suspended even though the problems of invasive species and deer browsing remain as serious as ever. Rhododendron removal is expensive $\left(€ 2,500-3,500 \mathrm{ha}^{-1}\right)$ and its profuse seeding means that regular inspection is needed to ensure control is effective. Deer control is also expensive because as the animals recolonise woodlands where fencing is inadequate. Culling is both difficult and expensive, especially when uncoordinated amongst neighbouring landowners.

An assessment of the effectiveness of the NWS was conducted by the authors. Ten native woodland areas were surveyed that were either privately or publicly owned. Six of the sites had received support through NWS1 and four were new woodlands supported by NWS2 (Table 1). Using their collective forestry expertise, the authors rated five attributes of natural capital value of each area on a scale of 1-5, where 1 indicated low potential and 5 high potential. The attributes were biodiversity, public recreation use, private use, water quality/angling and timber potential. Results of the scoring process indicated that each of the sites has potential to support biodiversity objectives by providing a diverse woodland habitat. Eight of the sites lie within the catchment of watercourses and three of these are of angling or amenity value and have the potential to contribute to improved water quality, moderate run-off and improve salmonid habitat. However, significant problems with deer were evident at six sites or invasive plant species at five sites. Only six of the ten sites were given ratings for public recreation. Four of these were considered to have moderate potential (i.e. a score of 3 or higher). The three sites rated for private use all had moderate potential.

In view of high importance of cultural services described above, the results of this survey suggest ways 
Table 1 Assessment of potential natural capital value and possible threats to ten native woodland areas that have received NWS support since 2003.

\begin{tabular}{|c|c|c|c|c|c|c|c|c|c|c|}
\hline \multirow[t]{3}{*}{ Parameter } & \multicolumn{10}{|c|}{ Woodland Location } \\
\hline & \multirow[t]{2}{*}{ Sligo } & \multirow[t]{2}{*}{ Galway } & \multirow[t]{2}{*}{ Central Mayo } & \multicolumn{4}{|c|}{ West Mayo } & \multirow[t]{2}{*}{ Wicklow } & \multirow[t]{2}{*}{ Leitrim } & \multirow[t]{2}{*}{ Offaly } \\
\hline & & & & a & b & c & d & & & \\
\hline Date of inclusion in NWS & 2003 & 2005 & 2011 & 2008 & 2004 & 2008 & 2005 & 2008 & 2003 & 2003 \\
\hline Ownership & public & private & private & public & private & private & public & public & public & public \\
\hline Within $20 \mathrm{~km}$ of an urban area & $\checkmark$ & $x$ & $x$ & $x$ & $\checkmark$ & $x$ & $x$ & $\checkmark$ & $\checkmark$ & $\checkmark$ \\
\hline Grant Scheme & NWS1 & NWS1 & NWS2 & NWS2 & NWS2 & NWS1 & NWS2 & NWS1 & NWS1 & NWS1 \\
\hline Area (ha) & 60 & 24 & 5.7 & 7.8 & 20 & 5 & 8 & 20 & 40 & 107 \\
\hline \multicolumn{11}{|l|}{ Natural capital value score } \\
\hline Biodiversity & 5 & 5 & 3 & 5 & 5 & 5 & 4 & 5 & 5 & 5 \\
\hline Public recreation & 4 & - & 4 & 1 & - & 3 & - & 3 & - & 2 \\
\hline Private amenity use by owner & - & 3 & - & - & 3 & - & 4 & - & - & - \\
\hline Water quality / angling & 2 & 2 & 1 & 3 & 1 & 1 & - & 1 & - & 1 \\
\hline Timber potential & 1 & 2 & 4 & 1 & 4 & 1 & 2 & 1 & 3 & 5 \\
\hline \multicolumn{11}{|l|}{ Threat } \\
\hline Deer & $\checkmark$ & $x$ & $x$ & $x$ & $x$ & $\checkmark$ & $\checkmark$ & $\checkmark$ & $\checkmark$ & $\checkmark$ \\
\hline \multicolumn{11}{|l|}{ Grey squirrel } \\
\hline Invasive plant species ${ }^{a}$ & $\checkmark$ & $\checkmark$ & $x$ & $x$ & $x$ & $\checkmark$ & $x$ & $x$ & $\checkmark$ & $\checkmark$ \\
\hline
\end{tabular}

a invasive species, e.g. rhododendron

in which more support from the NWS could increase the natural capital value of native woodland. In particular, a more strategic and targeted approach to planting could increase public and private benefits by focusing incentives on the ecosystem service value of woodland. Support for planting broadleaf species has proven to be popular with landowners and local communities for a variety of reasons including amenity, biodiversity and timber production. However, the levels of promotion and financing have been inadequate to foster a coordinated approach. Forest Service officials are working to promote coordination between forest and agricultural agencies and amongst landowners at local level. Successful targeting to maximise ecosystem service values can only be achieved by cultivating a high awareness of the scheme benefits, including ecosystem services, based on sustained support and grant availability.

\section{Opportunities}

Potentially, expanding the area of native woodland could generate substantial economic value. Biodiversity could be increased, particularly if new plantings were intentionally located to provide connectivity between existing scattered woodlands and/or with ancient woodlands. The relatively high value placed by the public on the amenities associated with new mixed and deciduous woodland (Upton et al. 2012a) (including the prospect of wildlife sightings) also means that new woodlands could provide recreation opportunities, with added benefits to health and specialist tourism. These benefits would follow particularly if plantings were located close to towns or areas that currently have limited natural recreation destinations. Some transfer of recreation from exotic forests might also occur. However, extrapolation of earlier estimates of use by infrequent woodland visitors suggests that an expansion of native woodland to an area equaling that of the total current forest could attract 15\%-20\% more visits overall.

At present, the value of regulating ecosystem services is small simply because the area of woodland is small. However, a coordinated expansion of woodland along rivers that are important to wildlife or for water abstraction would do much to protect against bankside erosion and to improve water quality. There could be additional benefits in terms of reduced costs for water purification and the treatment of waste water required to avoid adding further nutrients into the ecosystem. ${ }^{\text {xiii }}$ Coordinated planting of riversides and catchments could further improve salmonid habitats and the angling value of rivers.

An expansion of woodland area should also contribute to the moderation of flood risk as discussed above. Although this impact on downstream flooding may apply only up to a threshold, any relief would be welcome given that considerable costs associated with flooding, especially in catchments containing urban areas. Damage from flooding in Cork City in 2009 is estimated to have cost $€ 80-€ 100$ million. $^{\text {xiv }}$ Although it would not have prevented this particular incident, allocating a proportion of catchment area to woodland or alluvial woodland could contribute to a reduction in this risk.

Carbon sequestration by Irish native woodland is currently low as noted above. However, trees planted under the NWS are already contributing to the carbon balance. 
An expansion of woodland to an area equal to that of the current forested area could ultimately provide for the sequestration of $1.4 \mathrm{~m} \mathrm{t} \mathrm{C} \mathrm{yr}^{-1}$ on the basis of the indices referenced earlier. This sequestration would be worth $€ 100$ million per year on the basis of an average $\mathrm{CO}_{2}$ value of $€ 20$ per tonne on the European Emissions Trading Scheme or as much as $€ 180$ million per year if priced in terms of reduced abatement costs. ${ }^{x v}$

The regular thinning of woodland is compatible with net sequestration. Thinnings can contribute to renewable energy targets without impacting on tree growth. Should trees ultimately be harvested for roundwood, an expansion equal to the current area of forest could add 280 million $\mathrm{m}^{3}$ over the full rotation. In gross terms, this would be worth $€ 200$ million per year or $€ 60$ million in thinnings, although this figure includes state-transfer payments. In practice, the actual output of wood products would depend on the objectives of woodland owners. Rather few owners have been disposed to plant for timber as income fails to cover costs until near the end of the rotation period (Phillips 2006), at least prior to the recent upsurge in the value of thinnings. Nevertheless, the potential is there to create a more sophisticated and valuable hardware sector.

Approximate estimates of the current economic value of natural ecosystem services provided by Ireland's native woodland are shown in Table 2 . This Table also contains an illustration of the possible benefits resulting from an expansion of woodland by up to $25 \%, 50 \%$ or $100 \%$ of the total current forested area. The risk of double counting in relation to health, biodiversity or carbon sequestration is limited, as noted above. Those estimates associated with greater levels of expansion are inevitably more uncertain as there is insufficient information to suggest where woodlands would be planted. A halving of the visitor willingness-to-pay values, wood product and fuelwood values would similarly reduce the estimated economic benefits of expanding the current forest area. Diminishing returns could eventually set in for some ecosystem services such as amenity, while for others, such as timber and fuelwood, the future market situation and response of landowners is uncertain. An expansion of this scale is more likely within certain areas equivalent to $25 \%$ overall but with the possibility that health- and water-related benefits could be triple those given below.

\section{Discussion}

A lack of primary data on many ecological functions frustrates attempts to translate the benefits of ecosystem services into tangible economic outcomes. Our estimates of the natural capital value of Ireland's native woodland are necessarily approximate. Nevertheless, they provide evidence that this type of woodland has considerable economic importance and that this should not be ignored.

There is little doubt that native woodland is currently threatened by spatial fragmentation, invasive species, deer browsing, poor management and inconsistent state support for native forestry (Perrin et al. 2008; NPWS 2008; Purser et al. 2009). Native forest resources are under pressure from land-use change in developed and developing countries. Such changes include forest plantations comprised of fast-growing non-native species and urban development. In many countries, the loss of native forests has had serious negative consequences including loss of biodiversity, increased landslides, soil erosion and flash flooding, and deteriorating water quality. Given Ireland's temperate climate, the loss of ecosystem services provided by native woodland may appear to be relatively minor. Well-managed coniferous plantation forests planted on appropriate soil types should not have a negative impact on water quality and can still provide for amenity and habitat for more generalist species (Pithon et al. 2005; Irwin et al. 2013). However, while coniferous plantation provides a baseline level of public goods, the public good value of native woodland is likely to be much greater.

What is more pertinent is the opportunity cost of failing to take into account the potential ecosystem service values that could be realised by an expansion of native woodland beyond its current very limited area. An expansion would provide for more diverse types of recreation, associated tourism income and benefits to health. It would provide a long term carbon store, but also an option value for a future wood processing and for climate change. If the expansion is targeted so that the forested area approaches $20 \%-30 \%$ of land area as advocated by Peterken (2002), there is the potential to realise benefits from specialist recreation/tourism and biodiversity protection through the connection of isolated pockets of woodland. Significant cumulative benefits would also emerge for water quality, aquatic ecology and the management of water supplies and flooding. To realise these ecosystem service benefits at lower levels of tree cover, would require rather precise targeting that will not always be feasible or practical in a context of private land ownership.

\section{Conclusion}

This paper has summarised the arguments for the protection and expansion of native woodlands. It has demonstrated that native woodland has a significant natural capital value realised in terms of the contribution of a variety of ecosystem services for human welfare. The current area of native woodland covers just $1.4 \%$ of Ireland's land area but is estimated to provide an ecosystem service value of between $€ 67$ and $€ 76$ million per year. In common with other countries, much of this economic value is threatened from a variety of sources including 
Table 2 Approximate economic value of benefits from native woodland in Ireland - current and projected (€ millions per annum)

\begin{tabular}{|c|c|c|c|c|c|c|c|c|}
\hline \multirow[t]{2}{*}{ Area/type of estimate } & \multicolumn{8}{|c|}{ Ecosystem benefit ( $€$ millions per annum) } \\
\hline & Amenity & Tourism & Health & Water/ flood & Carbon & $\begin{array}{l}\text { Wood } \\
\text { products }\end{array}$ & Fuel wood & TOTAL \\
\hline \multicolumn{9}{|l|}{ Existing woodland } \\
\hline Best estimate & 35 & 24 & $2-3$ & $<1$ & $2-8$ & 1.4 & $2-4$ & $67-76^{d}$ \\
\hline \multicolumn{9}{|c|}{ Possible additional future area } \\
\hline $25 \%$ & 65 & 40 & 4 & 3 & 45 & 25 & 12 & 194 \\
\hline $50 \%$ & 120 & 50 & 6 & 6 & 90 & 50 & 24 & 346 \\
\hline $100 \%$ & $150^{\mathrm{a}}$ & 60 & 7 & 10 & $178^{b}$ & $100^{c}$ & 46 & 551 \\
\hline
\end{tabular}

a based on total forest amenity value of $€ 236 \mathrm{~m}$, or a net $€ 48 \mathrm{~m}$ addition after displacement from conifer plantations.

$\mathrm{b}$ representing an average of values while increased area is in growing phase and excluding carbon storage value.

c minimum roadside value after approximately 100 years, assuming that half the area is un-harvested or contains lower value species.

d figure excludes direct value for diodiversity and applies a lower range estimate for tourism compared with report produced for Woodlands of Ireland.

fragmentation, invasive plant species, overgrazing/browsing and lack of management. Some of these problems are so severe that they can only be controlled through sustained public funding and coordination between landowners. To date, state support for restoration, management, promotion and coordination has been inconsistent and inadequate relative to the benefits supplied by native woodlands.

Significant economic benefits could be realised through an expansion of the area of native woodland. In particular, there are potential cumulative benefits to recreation, tourism and biodiversity protection. The targeting of support would ensure that these ecosystem services are accompanied by significant benefits to water quality and management. There is an opportunity to realise significant economic value where concentrated strategic planting can replace the current fragmented wooded landscape with diversity and connectivity.

\section{Endnotes}

${ }^{\mathrm{i}}$ Figures provided by National Parks and Wildlife Service including Perrin et al. (2006)

${ }^{\text {ii }}$ http://ec.europa.eu/environment/nature/biodiversity/ comm2006/2020.htm

ii The figure was provided by Coillte (http://www. coillte.ie/aboutcoillte/recreation) for visits to its own landholding, although this represents the bulk of accessible forest in Ireland. The figure equates to that given that Fitzpatrick Associates (2005) based on the median number of visits (6) made by people interviewed in forests.

iv The authors estimated the share of visits based on frequency (as reported by Fitzpatrick Associates 2005) as a proportion of the adult Irish population of $2.5 \mathrm{~m}$. They then multiplied these figures by the number of visits for the respective population subsets multiplied by the average willingness-to-pay value for each subset. The estimated average willingness-to-pay values were: $€ 3.64$ for frequent visits (>34 times per year); $€ 7$ (where
$<34$ times per year); and $€ 20$ for specialist visitors (assumed 10 times per year). The total figure calculated in this way ( $€ 168$ million per year) compares with $€ 97$ million per year estimated by Fitzpatrick Associates (2008) based on 18 million visits at an average willingness-to-pay of $€ 5.42$.

v Sources: http://www.npws.ie/publications/archive/ KNPMP.pdf and http://www.wicklowmountatainsnationalpark.ie

${ }^{\mathrm{vi}}$ Insurance Ireland press release $(11 / 2 / 14)$. Insurance Ireland Members Estimate Claims Cost for December/ January Floods and Storms at $€ 46$ million.

vii Figures are a mixture of those produced by Indecon (2003) and others obtained through personal communication with Inland Fisheries Ireland representatives in County Mayo.

viii Figures provided by the Forest Service for 19982010.

ix Cannell \& Milne (1995) estimated total storage for oak woodland at $211 \mathrm{t} \mathrm{C} \mathrm{ha}^{-1}$.

${ }^{x}$ Current timber prices are available from Coillte (http://www.coillte.ie/) and the Irish Timber Growers' Association Forestry Yearbook, but hardwood supplies are sporadic and prices were obtained through consultation with three milling companies. Phillips (2006) notes that "there is no index" and quotes figures from Carey \& O'Connor (2004).

${ }^{x i}$ See, for example, http://www.teagasc.ie/forestry/ docs/advice/Teagasc_wood_energy_guide_edition3.pdf

xii According to Coillte, Newtownmountkennedy, Ireland; http://www.coillte.ie/

${ }^{\text {xiii }}$ For a discussion of the benefits see http://www. ecorisk.ie Chapter 3 "Water".

xiv Owens McCarthy insurance assessors as quoted in The Irish Times (18/7/02)

${ }^{\mathrm{xv}}$ As proposed by the UK Department of Energy and Climate Change (2009). 


\section{Competing interests}

There are none.

\section{Authors' contributions}

$\mathrm{CB}$ is the principal author. Information for the sample, on silviculture practice and timber has been provided by JH. Editing input has been provided by DL.

\section{Authors' information}

Craig Bullock is a research fellow within the School of Geography, Planning and Environmental Policy at University College Dublin and also manages Optimize (http://www.optimize.ie), an independent environmental and socioeconomic consultancy.

Jerry Hall is a forester with expertise in native woodlands. He manages Sylviron (http://www.sylviron.com), a forestry consultancy.

Declan Little is the manager of Woodlands of Ireland (http://www. woodlandsofireland.com), an environmental NGO which promotes the sustainable management and expansion of native woodlands.

\section{Acknowledgements}

The paper summarises some of the issues and economic estimation undertaken in a recent report prepared for Woodlands of Ireland, The Natural Capital Value of Native Woodland in Ireland. Detailed acknowledgements are given in this report. There are no direct references which have been provided by any individual in the paper.

\section{Declaration}

Publication of this supplement was funded by the New Zealand Forest Research Institute Limited (trading as Scion).

This article has been published as part of JOURNAL Volume 44 Supplement 1, 2014: Proceedings of the Third International Congress on Planted Forests. The full contents of the supplement are available online at http://www. nzjforestryscience.com/supplements/44/S1

\section{Authors' details}

'University College Dublin, Dublin 4, Ireland. '25ylviron, Turlough, Castlebar, Co. Mayo, Ireland. ${ }^{3}$ Woodlands of Ireland, Wicklow Enterprise Park, the Murrough, Wicklow, Ireland.

Published: 26 November 2014

\section{References}

Allott N, Brennan M, Cooke D, Reynolds J, Simon N: AQUAFOR Report 4 Steam chemistry, hydrology and biota Galway-Mayo region. In A study of the effects of stream hydrology and water chemistry in forested catchments on fish and macroinvertibrates. Dublin, Ireland; COFORD 1997:

Bailey N, Lee JT, Thompson S: Maximising the natural capital benefits of habitat creation: Spatially targeting native woodland using GIS. Landscape and Urban Planning 2006, 75:227-243.

Barron C: The control of rhododendron in native woodlands. In Forest Service Native Woodland Scheme Information Note No 3 D. Little 2007 [http://www. woodlandsofireland.com/sites/default/files/Rhodo.pdf].

Black KG, Byrne KA, Gallagher G: Implications for national reporting. In Carbon sequestration and irish Forest Ecosystems. Dublin: COFORD; K. G. Black, \& E. P. Farrell 2006:61-66

Blackstock P, Binggeli P: Development of a market strategy for domestic fuelwood in Ireland. Portadown, Northern Ireland: UAOS Limited; 2000 Broadmeadow S, Nisbet TR: The effects of riparian forest management on the freshwater environment: A literature review of best management practice. Hydrology and Earth System Sciences 2004, 8(3):286-305.

Byrnes E: A history of woodland management in Ireland: An overview. In Forest Service Native Woodland Scheme Information Note No 2 D. Little 2007 [http://www.woodlandsofireland.com/sites/default/files/

Woodland_Management_History.pdf].

Cannell MGR, Milne R: Carbon pools and sequestration in forest ecosystems in Britain. Forestry 1995, 68(4):361-375.

Carden RF, Carlin CM, Marnell F, McElholm D, Hetherington J, Gammell MP. Distribution and range expansion of deer in Ireland. Mammal Review 2011, 41: 313-325

Christie M, Hanley N, Garrod B, Hyde T, Lyons N, Bergmann E, Hynes S: Valuing heterogeneity of forest recreation activities: final report. Edinburgh: Forestry Commission 2006
CJC Consulting: Economic benefits of accessible green spaces for physical and mental health. CJC Consulting with Prof Ken Willis and Dr Liesl Osman: Final report for the Forestry Commission 2005.

Clinch JP: Cost-benefit analysis of Irish forest policy (Environmental valuation in developed countries). Cheltenham and Northampton, UK: Edward Elgar; 2006.

COFORD: Roundwood Demand Group. 2011

Cross J: Ireland's woodland heritage. 2012 [http://www.kcirishfest.com/images/ uploads/rish\%20Woodlands\%20booklet.pdf], Dublin: National Parks and Wildlife Service.

Cross JR: Biological flora of the British Isles. Rhododendron ponticum $L$ Journal of Biology 1975, 63:345-364.

DECC: Carbon valuation in the UK. Policy appraisal, a revised approach London: Department of Energy and Climate Change; 2009.

Dewar RC, Cannell MGR: Carbon sequestration in the trees, products and soils of forest plantations: an analysis using UK examples. Tree Physiology 1992, 11:49-71.

EPA: Water quality in Ireland 2007-2009. Dublin: Environmental Protection Agency 2010.

Fitzpatrick Associates: Economic value of trails and forest recreation in the Republic of Ireland. 2005, Dublin.

Forest Service: National forest inventory. Wexford: Department of Agriculture, Fisheries and Food; 2007, 271.

Forest Service: The second national forest inventory - Republic of Ireland results. Dublin: Department of Agriculture, Food and the Marine; 2012.

Foulkes N, Fuller J, Little D, McCourt SH: Hedgerow appraisal system. Best practice guidance on hedgerow surveying, data collation and appraisal. Dublin: Woodlands of Ireland; 2013 [http://www.heritagecouncil.ie/fileadmin/user_upload/ External_2013/HAS_Publication_FINAL_For_websites_July_2013_pdf].

Gallagher G, Dunne S, Jordan P, Stanley B: Ireland's forest inventory and planning system. Department of the Marine and Natural Resources 2001. Garrod GD, Willis KG: The non-use benefits of enhancing forest biodiversity: A contingent ranking study. Ecological Economics 1997, 21(17).

Gelan A, Slee B, Brown KM, Shannon P: Examining the commercial potential of recreation on the National Forest Estate in Scotland, Phase 1 Report. Edinburgh: Forestry Commission 2007.

Howley P, Ryan M, Donoghue CO: Forestry in Ireland: An examination of individuals' preferences and attitudes for the non-market benefits of forests. Irish Geography 2011, 44(2-3):291-302.

IFI: Wild salmon and sea trout statistics report. Dublin: Inland Fisheries Ireland 2011, 105.

Indecon: An economic/socio-economic evaluation of wild salmon in Ireland. Dublin: Indecon International Economic Consultants for Central Fisheries Board 2003.

Irwin S, Pedley SM, Coote L, Dietzsch AC, Wilson MW, Oxbrough A, Sweeney O, Moore KM, Martin R, Kelly DL, Mitchell FJG, Kelly TC, O'Halloran J: The value of plantation forests for plant, invertebrate and bird diversity and the potential for cross taxon surrogacy. Biodiversity and Conservation 2013, 23:697-714. Judd S, Rotherham ID: The Phytophagous insect fauna of Rhododendron ponticum L in Britain. The Entomoloist 1992, 111(3):134-150.

Kaplan S, Talbot JF: Psychological benefits of a wilderness experience. In Behavior and the Natural Environment. New York: Plenum;l Altman \& JJF Wohlwill 1983:163-203.

Kilfeather P: Fisheries and the aquatic environment. In Forests and Water: Cork E Henrick, \& L MacLennon 2000, 15 November 2000.

Laumann K, Garling T, Stormark KM: Selective attention and heart rate responses to natural and urban environments. Journal of Environmental Psychology 2003, 21:31-44.

Lehane BM, Walsh PM, Giller PS, O'Halloran J: The influence of small-scale variation in habitat on winter trout distribution and diet in an Afforested catchment. Aquatic Ecology 2001, 35:61-71.

Lehane BM, Giller PS, O'Halloran J, Smith CD, Murphy J: Experimental provision of large woody debris in streams as a salmonid management technique. Aquatic Conservation: Marine and freshwater ecosystems 2002, 12:289-311. Lehane BM, Giller PS, O'Halloran J: Relative influences of catchment geology and land use on brown trout populations in southwest Ireland. Biology and Environment 2004, 104B(1):43-54

Machava J, McCabe O, O'Dea P, Cabral R, Farrell E: Forestry operations and eutrophication - PEnrich. [Environmental Research Technological Development and Innovation (ERTDI) Programme 2000-2006 No.78] Johnstown Castle, Wexford: Environmental Protection Agency; 2007. 
Malcolm IA, Soulsby C, Hannah DM, Bacon PJ, Youngson AF, Telzlaff D: The influence of riparian woodland on stream temperatures: implications for the performance of juvenile salmonids. Hydrological Processes 2008, 22:968-979. Neary DG, Ice GG, Jackson CR: Linkages between forest soils and water quality and quantity. Forest Ecology and Management 2008, 258:2269-2281.

Ni Dhubhain A, Gardiner J, Davies J, Hutchinson WG, Chilton SM, Thompson K, Psaltopoulos D, Anderson C: The socio-economic impacts of afforestation on rural development: Final Report to CAMAR, European Community. Dublin: University College; 1994

NPWS: The Status of EU Protected Habitats and Species in Ireland. National Parks and Wildlife Service, Department of the Environment, Heritage and Local Government 2008

O'Brien L, Murray R: A marvellous opportunity for children to learn: A participatory evaluation of Forest School in England and Wales. Farnham, UK: Forest Research 2005 [http://www.forestry.gov.uk/pdf/fr0112forestschoolsreport. pdf/\$FILE/fr0112forestschoolsreport.pdf].

Penning-Rowsell E, Floyd P, Ramsbottom D, Surendran S: Estimating injury and loss of life in floods: A deterministic framework. Natural Hazards 2005,

36:43-64.

Perrin $\mathrm{PM}$, Daly $\mathrm{OH}$ : A provisional inventory of ancient and long-established woodland in Ireland. [Irish Wildlife Manuals, No 46] Dublin: National Parks and Wildlife Service, Department of the Environment, Heritage and Local Government.; 2010 [http://www.botanicalenvironmental.com/wp-content/ uploads/2010/02/Perrin-Daly-2010-ALEW-IWM.pdf]

Perrin PM, James M, Barron S, O'Neill F, NcNutt K, Delaney A: National Survey of Native Woodlands 2003-2008 - Volume 1; Main Report. BEC Consultants for National Parks and Wildlife Service 2008 [http://www.botanicalenvironmental.com/ wp-content/uploads/2011/03/Nolume-l.pdf].

Perrin PM, Martin JR, Simon JB, Roche JR: A cluster analysis approach to classifying Irish native woodlands. Biology and Environment: Proceedings of the Royal Irish Academy 2006, 106B(3):261-275.

Peterken G: Reversing the habitat fragmentation of British woodlands.

Godalming, UK: World Wide Fund for Nature; 2002.

Phillips H: Economic analysis of broadleaf afforestation. Irish Forest Industry

Chain 2006 [http://www.inff.ie/cmsfiles/pdf/henry_phillips_report.pdf].

Pithon JA, Moles R, Halloran JO: The influence of conifers on lowland farmland birds. Land Use Policy 2005, 71:91-103.

Purser P, Wilson F, Carden R: Deer and Forestry in Ireland: A Review of Current Status and Management Requirements. Woodlands of Ireland 2009.

Quine C, Cahalan C, Hester A, Humphrey J, Kirby K, Moffat A, Valatin G:

Woodlands. UK national ecosystem assessment Cambridge, UK: UNEP-WCMC;

2011.

Regeneris: The economic contribution of the Mersey Forest's objective one

funded investments. Manchester, UK: Regeneris Consulting; 2009.

Scarpa R, Chilton SM, Hutchinson WG, Boungiorno J: Valuing the recreational

benefits from the creation of nature reserves in Irish forests. Ecological

Economics 2000, 33(13)

Soulsby C, Reynolds R: Hydrological impact of broadleaf forests in the British uplands: Implications for water use and water quality. XXI General Assembly of the International Union of Geology and Geophysics 1-14 July 1995, Boulder, Colorado 1995.

Stithou M: The economic value of improvements in the ecology of Irish rivers due to Water Framework Directive. Stirling, UK: University of Stirling; 2011. Sunderland T: Microeconomic evidence for the benefits of investment in the environment - review. Bristol, UK: Natural England; 2012, [Natural England Research Reports, No. 033].

Sweeney O, Wilson M, Irwin S, Kelly T, O'Halloran J: Are bird density, species richness and community structure similar between native woodlands and non-native plantations in an area with a generalist bird fauna? Biodiversity and Conservation 2010, 19:2329-2342.

Thomas H, Nisbet TR: An assessment of the impact of floodplain woodland on flood flows. Water and Environment Journal 2007, 21(2):114-126.

Ulrich RS: Aesthetic and affective response to the natural environment. In

Human Behavior and the Natural Environment. New York: Phelum; I. Altman, \& J. F. Wohlwill 1983:

Upton V, ni Dhubhain A, Bullock C: Preferences and values for afforestation: the effect of location and respondent understanding on forest attributes in a labelled choice experiment. Forest Policy and Economics 2012a, 23:17-27. Upton V, Ni Dhubhain A, Bullock C: The valuation of non-market forest benefits in Ireland: A review. Irish Forestry 2012b, 68:63-76.
Valatin G, Starling J: Valuation of ecosystem services provided by UK woodlands. 2010, [UK National Ecosystem Assessment Economic Analysis Report].

doi:10.1186/1179-5395-44-S1-S4

Cite this article as: Bullock et al.: Realising the ecosystem-service value of native woodland in Ireland. New Zealand Journal of Forestry Science 2014 44(Suppl 1):S4.

\section{Submit your manuscript to a SpringerOpen ${ }^{\mathcal{O}}$ journal and benefit from:}

- Convenient online submission

- Rigorous peer review

- Immediate publication on acceptance

- Open access: articles freely available online

- High visibility within the field

- Retaining the copyright to your article

Submit your next manuscript at $>$ springeropen.com 